\title{
Camat Sebagai Pengawal Agenda Pembangunan (Studi Pada Tugas dan Fungsi Camat di Pemerintah Kabupaten Pandeglang)
}

\author{
Arif Nugroho, Fikri Habibi \\ Program Studi Administrasi Publik \\ Fakultas Ilmu Sosial Ilmu Politik dan Ilmu Hukum \\ Universitas Serang Raya \\ ariyul@gmail.com
}

\begin{abstract}
Abstrak
Artikel ini membahas tentang Tugas dan Fungsi Camat dalam pembangunan. Keberadaan agenda pembangunan Kabupaten Pandeglang serta Program Strategi Nasional di Kabupaten Pandeglang di tengah rendahnya progress IPM (Indeks Pembangunan Manusisia) selama beberapa tahun terakhir serta tantangan kultur dan nilai - nilai yang menjadi primordialisme masyarakat setempat membawa pada pentingnya kreatifitas camat/kecamatan sebagai perangkat daerah urusan kewilayahan untuk menjalankan tugas fungsi dan kewenangan legalnya dalam pembangunan agar kinerja pembangunan di Kabupaten Pandeglang dapat berjalan secara efektif. Penelitian dilakukan dengan pendekatan kualitatif, dan hasil penelitian menunjukan bahwa secara adminisratif kinerja camat/kecamatan dapat dikatakan cukup berhasil hal itu dilihat dari kemauan camat untuk mendayagunakan kreatifitas dalam merealisasikan agenda pembangunan yang telah ada sesuai tugas, fungsi dan kewenaganya. Namun ketika dilihat dari implikasi terhadap pertumbuhan IPM, belum cukup berhasil hal itu ditandai dengan belum signifikanya pertumbuhan IPM hal itu disinyalir karena beberapa hal yang belum dipotimalkan pelaksanaanya oleh Kecamatan dan Pemerintah Kabupaten Pandeglang salah satunya seperti momentum keberadaan program strategi nasional yang seharusnya dimanfaatkan sebagai peluang untuk memberikan dukungan agenda pembangunan di daerah.
\end{abstract}

Kata Kunci : Pemerintah Daerah, Camat/ Kecamatan, Pembangunan, Sub district Management

\begin{abstract}
This article discusses the Tasks and Functions of Camat in development. The existence of the Pandeglang District development agenda and the National Strategy Program in Pandeglang District amid the progress of the HDI (Manusia Development Index) in the last few years and the challenges of culture and values that become the primordialism of the local community led to the importance of sub-district / sub-district creativity as a regional apparatus to carry out the duties and functions of its legal authority in development so that the development performance in Pandeglang Regency can run effectively. The research was conducted with a qualitative approach, and the results of the study showed that administratively the performance of the sub-district / sub-district could be quite successful, it was seen from the willingness of the subdistrict head to utilize creativity in realizing the existing development agenda according to his duties, functions and authority. However, when viewed from the implications for the growth of HDI, it was not successful enough, it was marked by the insignificant growth of the HDI, presumably because some of the sub-district and Pandeglang District government had not maximized the momentum of the existence of a national strategy program that should be used as an opportunity to provide support for the development agenda in the region.
\end{abstract}

Keywords: Local Government, Subdistrict / District, Development, Sub District Management 


\section{A. PENDAHULUAN}

Secara Nasional IPM (Indeks Pembangunan Manusia) Indonesia mengalami peningkatan berdasarkan sumber UNDP (United Nations Development Programme) tahun 2016, tercatat untuk laki-laki 0,712 dan perempuan 0,66 didorong oleh beberapa faktor yakni kenaikan pendapatan per kapita hingga 135,4 persen, peningkatan angka harapan hidup menjadi 5-8 tahun antara 1990-2015. dikutp dari kabar24.bisnis.com. 22 Maret 2017 Namun fakta yang terjadi Kabupaten Pandeglang dari kurun waktu tahun 2015 hingga saat ini tahun 2018 masih belum mengalami peningkatan signifikandikutip dari Bantenheadline, 29 Maret 2018 kondisi IPM Pandeglang hanya bertambah sebesar 0.68 dari angka sebelumnya pada tahun 2015 sebesar 62.72. Begitu juga dengan rata-rata lama sekolah yang kini diangka 6.62 tahun. Atau hanya bertambah 0.02 tahun dari 6.60 ditahun 2015. Kabupaten Pandeglang masih membutuhkan perhatian khususnya pada sektor kemiskinan dan pendidikan dikutip dari poskotanews.com, 23 Maret 2016 bahwa pada tahun 2016 lalu Gubernur Banten Rano Karno menilai Kabupaten Pandeglang merupakan kabupaten yang harus mendapatkan perhatian khusus karena tingginya kesenjangan serta minimnya industri. Kemudian Bupati Pandeglang Irna Narulita menyatakan bahwa melalui penetapan program strategi nasional di Kabupaten Pandeglang yang meliputi pembangunan Jalan Tol (Jalan Bebas Hambatan) yang terkoneksi dengan akses menuju ibu kota Negara, KEK (Kawasan Ekonomi Khusus) Tanjung Lesung diharapkan akan dapat mendongkrak pertumbuhan perekonomian.

\section{Pada dasarnya Pandeglang} memiliki potensi yang baik. Selain dengan pemerintah kabupaten, terjalinya sinergi antara masyarakat dengan investor adalah suatu hal yang dianggap penting. Adapun kendala yang dihadapi oleh Pemerintah Kabupaten Pandeglang dalam merealisasikan agenda - agenda pembangunan tersebut salah satunya adalah resistensi dari masyarakat dengan menitik beratkan pada pertentangan kultur dan nilai - nilai kehidupan masyarakat setempat. Burn et al, (1994:105) menjelaskan budaya organisasi adalah fenomena yang kompleks. Bersama budaya penggunaan layanan mengacu pada sistem ideologi masyarakat, nilai-nilai, seni pengetahuan, hukum dan ritual dari hari ke hari. Dalam teori organisasi metafora budaya digunakan untuk menunjukkan bahwa organisasi dapat dilihat masyarakat sebagai pola mini dengan kekhasan budaya dan subkultur mereka sendiri.

Dalam konteks penyelengaraan pemerintahan daerah kabupaten/kota dan pelaksanaan pembangunan daerah di Indonesia camat merupakan pimpinan Kecamatan sebagai perangkat daerah otonom. Menurut Schmid (1972) dikutip dari Hamudy ( 2009 :54) dalam konteks otonomi daerah kecamatan merupakan suatu sistem organisasi dan kontrol sumber daya yang kinerjanya ditentukan dengan pola relasi dengan kabupaten. Artinya Camat/Kecamatan sebagai perangkat kewilayahan pemerintah daerah memiliki konsekuensi dan integrasi sebagai daya dukung penyelenggaraan serta pembangunan pemerintahadan daerah baik pada kisaran urusan otonomi daerah, tuntutan orkestrasi program strategi nasional hingga yang tidak kalah pentingnya adalah pembangunan desa yang selama 
ini mendapatkan perhatian besar dengan dialokasikan Dana Desa bersumber dari APBN (Anggaran Pendapatan dan Belanja Negara). Butsankom et al (2016 : 1798) menjelaskan bahwa dalam mewujudkan efektivitas manajemen pada sub-district/ kecamatan diperlukan administrator dengan kriteria sebagai berikut; (1) Memiliki visi kepemimpinan kreatif dalam berpikir, (2) Dapat beradaptasi dan berkembang terus menerus, (3) Mampu memecahkan masalah dengan efektif, (4) Dapat menentukan visi, misi dan tujuan operasi yang jelas, (5) Memiliki dukungan interaksi kelompok melalui kepemimpinan partisipatif, (6) Telah merencanakan manajemen operasi dengan situasi saat ini.

Adapun kompilasi artikel ilmiah tentang relevansi camat/kecamatan dalam pembangunan diantaranya (1) Abbott et al (2015) menjelaskan bahwa dalam konteks pembangunan, konsep orkestrasi sebagai perantara mobilisasi orkestra (yang dilakukan oleh pemerintah) secara sukarela dalam mencapai tujuan pemerintahan bersama. Hasilnya menunjukan bahwa orkestrasi relatif lebih mungkin diterapkan pada sistem demokratis daripada sistem otoriter. Orkestrasi tidak selalu lebih diinginkan daripada delegasi, tetapi memberikan alternatif penting pada beberapa keadaan. (2) Kemmochi et al (2016) dalam artikelnya mengkaji penerapan decentralization in cities pada beberapa kota di jepang. Hasilnya menunjukan bahwa decentralization in cities semakin diperkenalkan guna memainkan peran sentral dalam mengkonsolidasikan berbagai pendapat dari warga negara dalam tahap perencanaan pembangunan kota. (3) Virajniphawan, (2536: 279) sebagaimana dikutip dari artikel Boonsiri dan Phiriyasamith (2016:64) dijelaskan bahwa bahwa Sub-district dianggap berfungsi memainkan peran penting dalam pembangunan administrasi. Selain itu juga dianggap sebagai unit administrasi kewilayahan yang memiliki potensi memainkan peran penting dalam memobilisasi dan memanfaatkan sumber daya eksternal di luar organisasi. Dari beberapa arikel yang ada pada intinya menjelaskan bahwa keberaan Subdistrict/ Kecamatan dalam tugas dan fungsinya dianggap penting sebagai daya dukung dalam merealisasikan agenda pembangunan baik pada daerah otomom itu sendiri maupun tuntukan orkestrasi pembagunan pemerintah secara nasional Dari uraian di atas, artiket ini membahas tentang tugas dan fungsi camat sebagai pimpinan kecamatan yang salah satu kedudukanya merupakan perangkat daerah otonom. Alasan Kabupaten Pandeglang dipilih sebagai lokus penelitian adalah selain permasalahan yang telah duraikan di atas penekanan pada fenomena pertentangan antara agenda pembangunan pemerintah daerah dengan kultur dan nilai nilai yang belaku di masyarakat setempat yang tidak sedikit mendapatkan penolakan. Kemudian tuntutan orkestrasi program strategi Nasional yang tinggi karena ditetapkanya Kabupaten Pandeglang sebagai salah satu daerah yang masuk dalan zona program strategi nasional. Untuk itu dianggap perlu kreatifitas camat sebagai pimpinan kecamatan yang notabene sebagai perangkat daerah untuk menjalankan tugas dan fungsi legalnya agar kinerja pembangunan di Kabupaten Pandeglang dapat berjalan secara efektif, sehingga hal itu dianggap sebagai sisi yang menarik untuk diteliti. 


\section{Diskusi Theori Sub - district Management}

Dalam buku World Bank and United Cities and Local Goverments (2008: 33) Afrika yang mengklasifikasikan otoritas lokal sesuai dengan tingkat perkembangan urbanisasi. Misalnya dalam menurunkan peringkat urbanisasi, Kamerun memiliki masyarakat perkotaan seperti komune perkotaan khusus di bawah skema komune perkotaan serta komune pedesaan. Klasifikasi di Afrika Selatan mengambil bentuk hirarki Kotamadya abjad dengan kategori $\mathrm{A}, \mathrm{B}$ dan $\mathrm{C}$. Diferensiasi ini seperti membuat lebih mudah dalam mengidentifikasi pihak yang paling dirugikan, dan kadangkadang disebut melalui proses pemerataan untuk fokus pada pengembangan mereka dengan dukungan kebijakan khusus.

Memahami sub-district adalah manifestasi dari konsep decentralization within cities serta sifat perubahan manajemen serta menemukan lingkungan desentralisasi sebagai salah satu strategi untuk memberikan bentuk tertentu. Burn et al, (1994:89) Memahami Sub district merupakan bentuk dari lokalisasi. Dimana pada saat ini terdapat banyak lokalisasi yang dapat dievaluasi sejauh mana lokalisasi tersebut mampu memenuhi tujuan (1) aksesibilitas fisik (2) keterbukaan dan (3) Kelengkapan. Fleksibilitas merupakan suatu pendekatan yang juga diperlukan dalam mengelola lingkungan desentralisasi. Kemudian Butsankom et al (2016 : 1797) menjelaskan faktor model manajemen efektivitas pada aspek input sub district terdiri dari tiga faktor: rencana strategis, tujuan misi dan kebijakan; sumber daya manusia, peralatan dan dana; lingkungan Hidup. Penekanan pada faktor sumber daya manusia yang perlu digaris bawahi adalah administrator sub district yang mampu mewujudkan tujuan dalam pengelolaan lingkungan desentralisasi. Terkait dengan itu dalam konteks sejarah di Indonesia Kurasawa (2015:467) menjelaskan bahwa pada masa penghapusan dualisme pemerintahan daerah oleh Jepang dari hirarki europees bestuur dan inlands bestuur bentukan pemerintah Hindia Belanda. onderdistrict/kecamatan berubah menjadi unit administrasi bernama Son dipimpin oleh Soncho difungsikan menyampaikan perintah dari pemerintah mengenai pelaksanaan kebijakan - kebijakan baru, Sonco kerap menampakan diri di hadapan masyarakat di bawah yuridiksinya didampingi para istri mereka, seorang Soncho jarang tetap tinggal di kantor dalam rangka memelihara fungsi fungsinya, karena hal itu hingga diangkat jabatan baru Fuku Soncho (wakil soncho).

\section{B. METODE PENELITIAN}

Penelitian yang disajikan dalam artikel ini menggunakan pendekatan kualitatif. Teknik pengumpulan data yang dilakukan meliputi wawancara, observasi, telaah dokumen yang meliputi ketetapan (hukum dan kebijakan), buku, artikel ilmiah, berita baik di media cetak maupun elektronik, serta laporan kinerja tugas, fungsi dan kewenangan camat/kecamatan. Penentuan informan pada penelitian ini menggunakan teknik purpossive sampling. Hal ini dimaksudkan bahwa informan ditetapkan berdasarkan kriteria khusus atau yang dianggap memahami permasalahan yang diteliti, sehingga layak digali informasinya melalui wawancara. Informan yang ditentukan, terdiri dari (1) Bupati/ diwakili Kepala Sub Bagian Bina 
Kewilayahan, (2) Anggota Komisi I DPRD, (3) (4) Camat dan jajaran (5) Perwakilan Kepala Desa, (6) Perwakilan pendamping desa. (7) Tokoh Masyarakat. Namun dalam penulisan artikel ini data yang dianggap representatif saja yang disajikan.

Teknik analisis data dalam penelitian ini menggunakan model analisis data interaktif dari Miles, Huberman dan Saldana (2014). Penggambaran model analisis datanya dilakukan dengan langkah-langkah sebagai berikut:(1) Kondensasi data (data condensation); (2) Penyajian data (data display); (3) Penarikan kesimpulan (conclusions drawing)

\section{HASIL DAN PEMBAHASAN}

\section{Menghadapi Kultur Masyarakat Dalam Pembangunan}

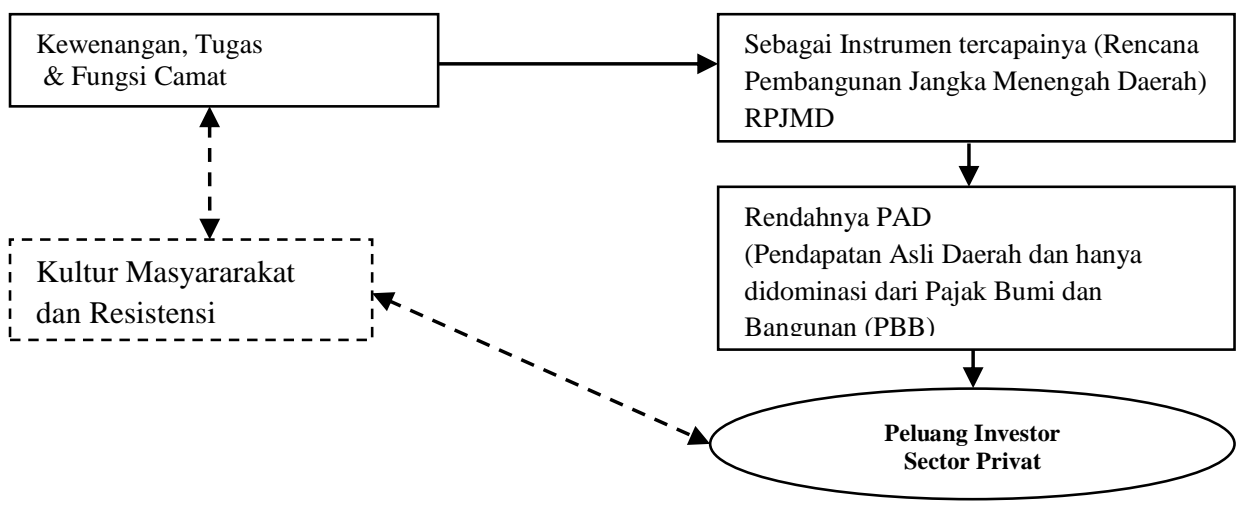

\section{Gambar 1. Kondisi Eksisting Hambatan Kultur Masyarakat pada Kinerja Pembangunan}

Berdasarkan gambar di atas dan hasil penelitian diketahui bahwa Kabupaten Pandeglang memiliki ketergantungan yang tinggi pendapatan asli daerah dari sector PBB (Pajak Bumi dan Bangunan). PBB tetap mendominasi selain penerimaan daerah dari sektor retribusi dan pajak lainya. Adapun data bahwa PAD (Pendapatan Asli Daerah) Kabupaten Pandeglang kurang lebih sebesar Rp. 197 miliar pada tahun 2017, sedangkan untuk tahun 2018 PAD Pandeglang ditargetkan meningkat menjadi sekitar Rp. 203 miliar.

Pada dasarnya pemerintah Kabupaten Pandeglang menyikapi hal itu telah melakukan langkah guna menggenjot penerimaan daerah dengan salah satunya dengan mengundang investor swasta untuk untuk berinvestasi namun terbentur dengan resistensi dari masyarakat karena adanya pertentangan kultur dan nilai nilai religiusitas yang telah menjadi primordialisme di kalangan masyarakat setempat.

Hal itu dapat dicontohkan pada Tanggal 11, November 2015 Ratusan warga Kecamatan Cadasari Kabupaten Pandeglang yang tergabung dalam jamiyatul muslimin menggelar istigasah di kawasan parkir DPRD Provinsi Banten menolak rencana 
didirikanya indusrti air mineral. Penolakan didasarkan atas sebuah asumsi jika Kabupaten Pandeglang menjadi daerah industri serta destinasi urbanisasi maka potensi kemaksiatan/pelanggaran terhadap kultur dan nilai nilai religiusitas meningkat di Kabupaten Pandeglang.

Melihat kendala semacam itu tentunya dianggap oleh pemerintah daerah khususnya Camat/kecamatan sebagai perangkat daerah kewilayahan merupakan dilema yang tidak sedikit berujung pada pilihan untuk berputus asa. Namun sebagian lagi menganggap sebagai sebuah tantangan yang harus dihadapi dengan mengawali dari sebuah sudut pandang bahwa permasalahan itu merupakan peluang sekaligus tantangan yang sejatinya masih bisa dikelola dan dicarikan jalan keluar dengan pendekatan cultural namun tetap dalam koridor ketaatan pada peraturan perundang undangan sebagai birokrasi penyelenggara pemerintahan daerah.

Penananaman modal swasta merupakan peluang bagi pemerintah daerah, utamanya sebagai struktur perekonomian daerah. Dalam hal itu camat sebagai pimpinan perangkat daerah kewilayahan sebagaimana dikutip dari Wasistiono et al (2009:233) menyebutkan terdapat Sembilan kewenangan yang didelegasikan kepada camat meliputi perizinan, rekomendasi, penetapan, fasilitasi, pembinaan, pengawasan, koordinasi, pengumpulan data dan penyampaian informasi.

Jika permasalahan resistensi dari masyarakat menjadi kecenderungan masyarakat Kabupaten Pandeglang, berdasarkan hasil pemetaan diketahui terdapat tiga pilihan sikap yang mungkin diambil oleh para camat yang Pertama dengan kewenangan yang dimiliki, camat berinisiatif memfasilitasi antara kepentingan masyarakat dengan kepentingan pihak swasta secara berimbang dengan menitik beratkan pada kesepakatan antara pihak swasta dengan masyarakat namun dengan tetap memegang teguh proses dengan nilai etika atau integritas, Kedua Camat memanfaatkan permasalahan dengan kewenangan yang dimilikinya tanpa menitik beratkan pada kepentingan masyarakat. Ketiga, karena keinginan tetap dianggap berintegritas, melihat permasalahan yang ada camat cenderung memilih pasif dan tidak berinisiatif apaapa.

Berdasarkan hasil penelitian diketahui kecenderungan camat di Kabupaten Pandeglang memiliki keinginan pada sikap yang pertama, karena sikap yang pertama merupakan sesuatu yang cukup rasional dan ideal sebagaimana seharusnya dilakukan oleh pimpinan perangkat daerah otonom sebagai daya dukung pembangunan daerah serta perwujudan daya saing daerah.

Dikutip dari Alrasyid (2007:4) menurut pandangan Hegel, jika warga dari suatu negara dibiarkan mengatur dirinya sendiri, maka akan terjadi kekacauan karena masing - masing warga akan memperjuangkan kepentingan subyektifnya melawan kepentingan subyektif warga lainnya. Kemudian untuk pilihan sikap yang kedua dan ketiga yang bisa dikatakan tidak menitik beratkan pada upaya mengakomodir kepentingan masyarakat serta terealisasinya investasi di daerah yang membawa pada faedah struktur ekonomi bagi pemerintah daerah, pembangunan kesejahteraan dan daya saing daerah.

Menurut perspektif Hegelian, birokrasi tak lain adalah medium yang mempertemukan kepentingan rakyat dan 
pemerintah. Berdasarkan perspektif ini berarti lahir sebuah aksioma, birokrasi mengemban tugas besar berupa harmonisasi hubungan antara rakyat dan pemerintah, bahkan mempersamakan geist rakyat dengan geist pemerintah.
Dalam posisinya sebagai medium itulah birokrasi menyucikan dan memurnikan diri untuk tak terjebak pada kepentingan subyektif.

\section{Membina dan Mengawasi Pembangunan Desa}

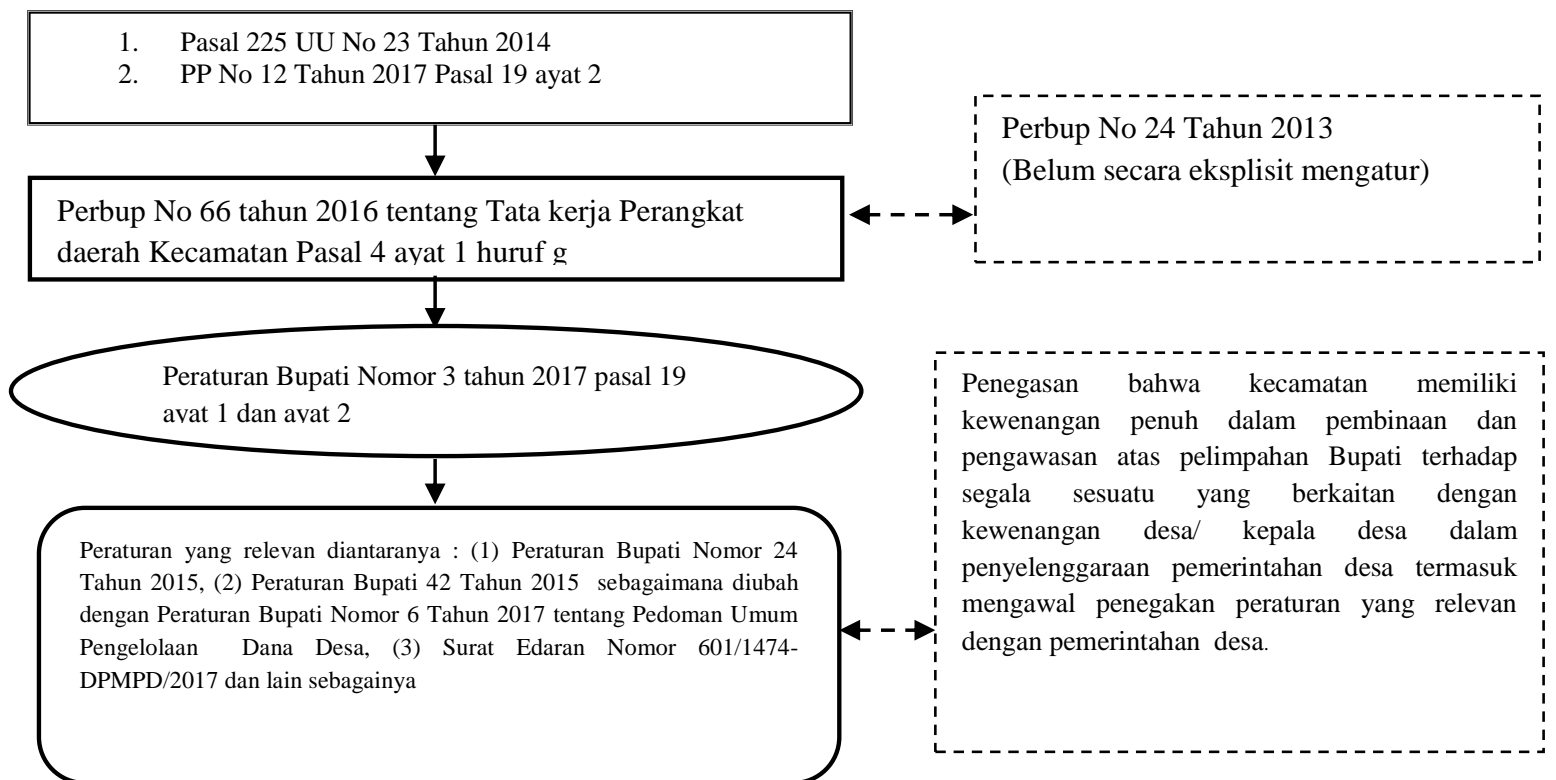

Gambar 2. Landasan Camat/Kecamatan Dalam Pembinaan dan Pengawasan Penyelenggaraan Pemerintahan Desa. Sumber : Data Diolah Peneliti 2017

Berdasarkan gambar di atas diketahui bahwa Konsekuensi camat/ kecamatan yang mengkoordinasikan desa dalam melaksanakan tugas dan fungsi pembinaan serta pengawasan terlihat lebih berat dari pada yang membawahi kelurahan. Hal itu sebagai konsekuensi dari diterapkannya Undang - Undang Nomor 6 Tahun 2014 tentang pemerintahan desa dan keberadaan camat yang difungsikan selain sebagai verifikator dana desa juga sebagai simpul pembina dan pengawas pemerintah Kabupaten Pandeglang pada pemerintah desa yang secara eksplisit dijelaskan dalam Pasal 225 UU No 23 Tahun 2014 ayat (1) huruf (g). Dengan kata lain kinerja pembinaan dan pengawasan terhadap salah satu urusan tersebut merupakan sebuah tantangan yang harus dihadapi oleh seorang camat/kecamatan untuk mewujudkan akuntabilitas dalam kinerja pembangunan desa. Kolopaking (2008) dikutip dari Mugito (2012) menjelaskan beberapa fungsi dan tugas pokok yang diharapkan tetap diperankan camat diantaranya (1) sebagai lembaga simpul pembangunan dan pemberdayaan masyarakat dan desa, (2) sebagai lembaga pengelola krisis dan tanggap darurat, (3) sebagai lembaga yang mendampingi penyelenggaraan pemerintahan desa di dalam kerangka 
memperkuat kapasitas pemerintahan desa.

Diketahui bahwa pada Peraturan Bupati Pandeglang Nomor. 24 Tahun 2015 secara operasioanal telah mengatur dan menegaskan kekuasaan yang dimiliki kepala desa pada pengelolaan keuangan desa serta kedudukan kepala desa sebagai wakil Pemerintah desa dalam kepemilikan kekayaan milik desa yang dipisahkan . Artinya perbup tersebut menjelaskan bahwa kepala desa berwenang untuk menetapkan kebijakan dalam pelaksanaan APBDes, menetapkan Pelaksana Teknis Pengelolaan Keuangan Desa (PTPKD) yang dikoordinatori oleh sekretaris desa dan beranggotakan perangkat desa lainnya.

Adapun digambarkan sebagai berikut;

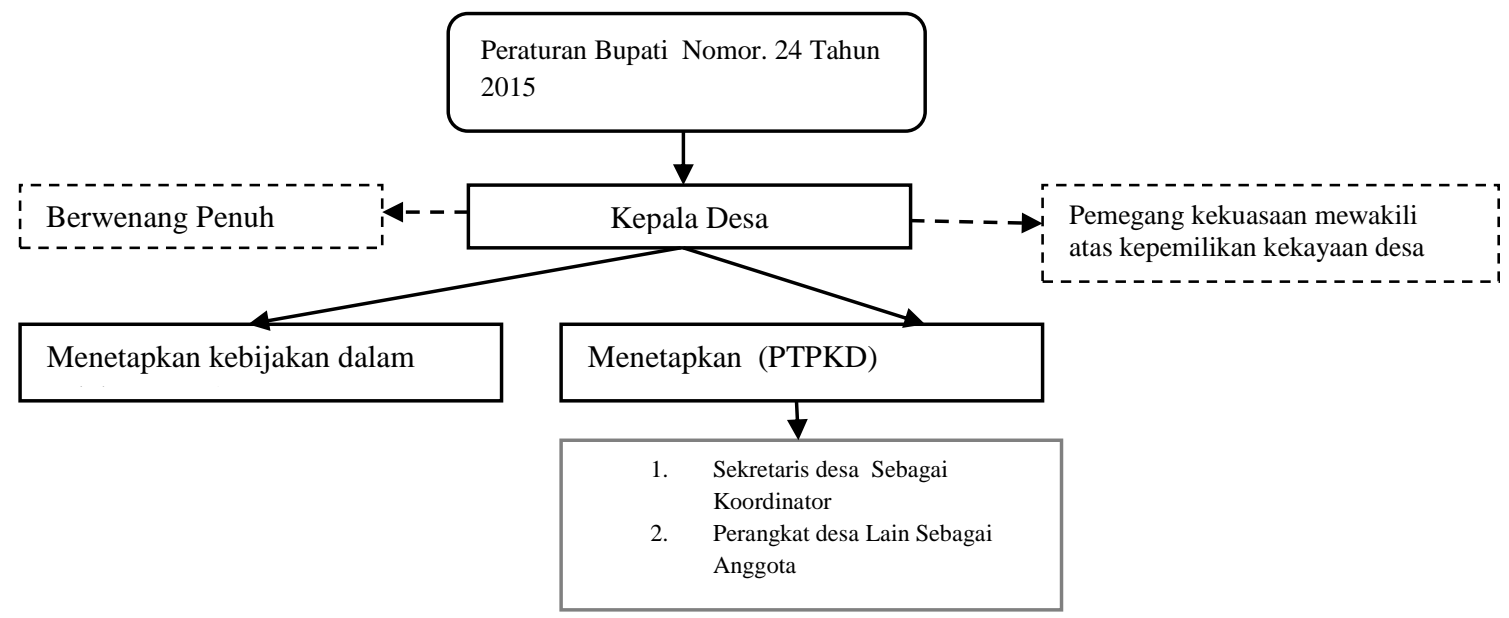

Gambar 3. Kekuasaan Kepala Desa Dalam Tata Kelola Keuangan Desa. (Sumber : data diolah peneliti 2017)

Lebih lanjut dalam rangka pengendalian implementasi kekuasaan kepala desa pada penatakelolaan keuangan desa. Secara operasional Peraturan Bupati Nomor 6 tahun 2017 telah mengatur sanksi berupa penundaan penyaluran dana desa jika kepala desa belum menyerahkan dokumen peraturan desa tentang APBDes pada Bupati pada pencairan tahap 1. Sedangkan ketentuan untuk pencairan tahap 2 laporan realisasi penggunaan anggaran tahap 1 telah disampaikan oleh kepala desa pada bupati dengan penggunaan dana tidak kurang dari 50\%. Jika hasil monitoring dan evaluasi terjadi SILPA (Sisa Lebih Penggunaan Anggaran) di Rekening Kas Desa (RKD) lebih dari 30\% pada tahun anggaran sebelumnya, maka Bupati dapat memerintahkan inspektorat kabupaten melakukan pemeriksaan. Jika ditemukan indikasi kesalahan, maka inspektorat dapat mengusulkan penundaan penyaluran dana desa tahun anggaran berikutnya 


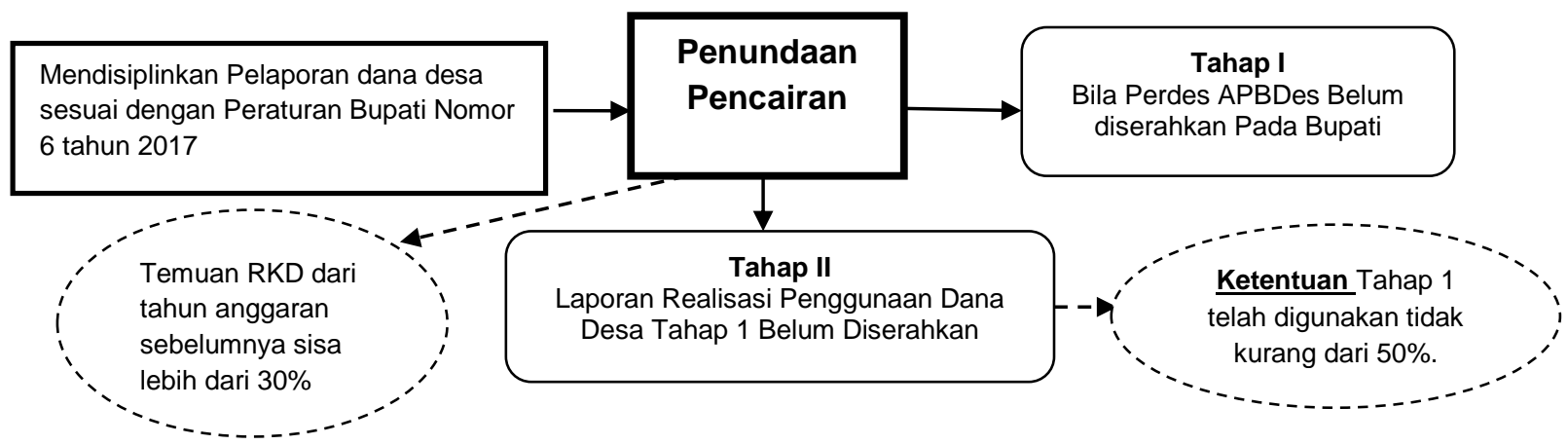

Gambar 4. Mekanisme Pengendalian Pengelolaan Dana Desa. (Sumber : data diolah peneliti 2017)

Dari hasil penelitian diketahui bahwa kendala yang dihadapi desa bermacam-macam, diantaranya curah hujan yang tinggi sehingga penyelesaian pekerjaan terhambat, kemudian kepala desa yang meninggal dunia, pengunduran diri dan pergantian perangkat desa sehingga informasi progress pekerjaan terputus. Dari 33 kecamatan yang wilayah kerjanya terdiri dari desa, pada tahun anggaran 2017 rata - rata terdapat 1 hingga 2 desa mengalami SILPA (Sisa Lebih Penggunaan Anggaran) lebih dari $30 \%$ pada tahun anggaran sebelumnya dan penggunaan anggaranya kurang dari $50 \%$ pada realisasi tahap 1 sebanyak 10 desa atau 3,1\% dari total 326 desa yang ada di Kabupaten Pandeglang.

$$
\text { Pada tahun } 2017 \text { Bupati }
$$

Pandeglang mengeluarkan Surat Edaran Nomor 601/1474-DPMPD/2017 tentang 10 program prioritas pembangunan yang meliputi Pembangunan Taman Pintar, Pembangunan Pos Yandu, Pembangunan Embung Desa, Jalan Desa (Paving Blok), BUMDes, Pembuatan Tempat Pembuangan Sampah, Sarana Olahraga, 1 desa 1 produk unggulan, Perikanan item, dan Wisata/sarana air bersih . Adapun Target Capaian dan Realisasi Kegiatan sebagai berikut:

Tabel 1.

Target Capaian dan Realisasi Kegiatan Prioritas Tahun 2017

\begin{tabular}{|c|c|c|c|c|c|c|}
\hline No & Target Capaian & Volume & Satuan & Realisasi & Volume & Satuan \\
\hline 1 & $\begin{array}{l}\text { Pembangunan Taman } \\
\text { Pintar }\end{array}$ & 100 & Unit & $\begin{array}{l}\text { Pembangunan Taman } \\
\text { Pintar }\end{array}$ & 100 & Unit \\
\hline 2 & $\begin{array}{l}\text { Pembangunan Pos } \\
\text { Yandu }\end{array}$ & 326 & Unit & Pembangunan Pos Yandu & 326 & Unit \\
\hline 3 & $\begin{array}{l}\text { Pembangunan Embung } \\
\text { Desa }\end{array}$ & 150 & Bangunan & $\begin{array}{l}\text { Pembangunan Embung } \\
\text { Desa }\end{array}$ & 148 & Bangunan \\
\hline 4 & $\begin{array}{l}\text { Jalan Desa (Paving } \\
\text { Blok) }\end{array}$ & 326 & Desa & Jalan Desa (Paving Blok) & 326 & Desa \\
\hline 5 & BUMDes & 326 & Desa & BUMDes & 326 & Desa \\
\hline 6 & $\begin{array}{l}\text { Pembuatan Tempat } \\
\text { Pembuangan Sampah }\end{array}$ & 150 & Unit & $\begin{array}{l}\text { Pembuatan Tempat } \\
\text { Pembuangan Sampah }\end{array}$ & 150 & Unit \\
\hline
\end{tabular}




\begin{tabular}{|c|c|c|c|c|c|c|}
\hline 7 & Sarana Olahraga & 150 & Unit & Sarana Olahraga & 150 & Unit \\
\hline 8 & $\begin{array}{l}1 \text { desa } 1 \text { produk } \\
\text { unggulan }\end{array}$ & 326 & Produk & 1 desa 1 produk unggulan & 326 & Produk \\
\hline 9 & Perikanan & 100 & Bagunan & Perikanan & 100 & Bagunan \\
\hline 10 & $\begin{array}{l}\text { Wisata/sarana air } \\
\text { bersih }\end{array}$ & 120 & Bangunan & Wisata/sarana air bersih & 120 & Bangunan \\
\hline
\end{tabular}

Sumber : DPMPD (Dinas Pemberdayaan Masyarakat dan Pemerintahan Desa) Pandeglang, 2017

Dari Tabel di atas diketahui bahwa 10 item pembangunan di desa dapat dikatakan mayoritas terealisasi namun hanya pada 2 pembangunan pembangunan embung desa saja yang tidak terealisasi sesuai dengan target. Terlihat bahwa dengan pencapaian pada 326 desa dari 33 kecamatan yang melakukan pembinaan pengawasan dan fungsi verifikasi terhadap pengelolaan dana desa perhatian dan energinya terfokus pada urusan itu. Dari hasil penelitian diketahui bahwa selain adanya kendala teknis dalam peñata kelolaan yang dikukan oleh desa, terdapat penolakan yang dilakukan oleh asosiasi pemerintahan desa Kabupaten Pandeglang terhadap prioritas pembangunan yang ditapkan oleh bupati dengan alasan bahwa prioritas pembangunan yang ditetapkan tidak merepresentasikan karakteristik dan kebutuhan desa. Turner and Hulme (1997) desentralisasi/mode menyerahkan pemerintahan akan lebih dekat dengan masyarakat, sehingga checks and balances dapat dilakukan dengan tujuan dapat mengontrol ekses pejabat pemerintah serta membuat mereka lebih responsif terhadap kebutuhan masyarakat. Lebih lanjut namun rupanya pemerintah kabupaten memiliki pandangan yang berbeda bahwa dengan adanya penetapan 10 program prioritas justru membuat pembangunan desa sebagai bagian dari pembangunan daerah semakin terarah dan terintegrasi dengan
RPJMD (Rencana Pembangunan Jangka Menengan Daerah) Kabupaten Pandeglang.

Di tengah dinamika itu kecamatan memainkan peran mengatasi permasalahan dengan memberikan pemahaman kepada desa tentang maksud dan tujuan program prioritas pembangunan. Hal itu dilakukan guna mengawal kebijakan yang telah ditetapkan oleh pemerintah Kabupaten Pandeglang, sehingga pada akhirnya desa memiliki kesadaran untuk melaksanakanya. Kim dan Joseph, (2002) dikutip dari Hamudy (2009 :54). bahwa property rights yang dimiliki kelembagaan kecamatan bermakna sosiologis. Artinya pengelolaan sumberdaya yang dilakukan dibatasi dalam kerangka otonomi daerah dan otonomi desa yang secara sosiologis tidak dapat dipisahkan dengan pengaturan oleh hukum positif, adat, dan tradisi, serta kesepakatan-kesepakatan sosial yang mengatur hubungan antarkomunitas desa terhadap sumberdaya.

Berdasarkan uraian di atas, terkait dengan legalitas tugas, fungsi dan kewenangan camat/kecamatan membina dan mengawasi penyelenggaraan pemerintahan desa khususnya pada aktifitas pembangunan desa dengan kekuasaan yang dimiliki oleh desa dan dinamika serta permasalahan yang ada, tentunya membawa camat/ kecamatan pada sebuah tanggung jawab yang cukup besar agar integrasi pembangunan desa 
sebagai bagian dari pemerintah daerah secara efektif dapat tercapai. Jalinan koordinasi dan sinergi yang berjalan dengan baik antara kecamatan dan desa dianggap penting. Hal itu tentunya dapat dilakukan dengan kreatifitas yang dimiliki camat dalam memainkan peranan sebagai simpul penghubung pemerintah kabupaten dengan desa. Maka dari itu Butsankom et al (2016 : 1798) bahwa dalam mewujudkan efektivitas manajemen pada sub-district/ kecamatan salah satunya harus memiliki visi kepemimpinan kreatif dalam berpikir serta mampu memecahkan masalah dengan efektif.

\section{Penyelenggaraan Musyawarah Perencanaan Pembangunan}

Penyelenggaraan Musrenbang

RKPD (Rencana Kerja Pembangunan Daerah) Kecamatan sebagainamana diatur pada Peraturan Pemerintah Nomor 17 Tahun 2018 pada pasal 17 Ayat (2) dijelaskan bahwa prencanaan pembangunan Kecamatan sebagaimana dimaksud pada ayat (1) merupakan bagian dari perencanaan pembangunan kabupaten/ kota. Kaitannya dengan Musrenbang, kedudukan kecamatan merupakan fasilitator yang bertugas menjembatani apirasi masyarakat tingkat Desa atau kelurahan dengan Pemerintah Kabupaten Pandeglang dalam perencanaan pembangunan melalui jaring aspirasi masyarakat. Kemmochi et all (2016) dalam kajianya atas survey di beberapa kota di jepang meliputi kota Toyota, Izumo, Tochigi dan Musashino bahwa decentralization in cities semakin diperkenalkan, karena diharapkan dapat memainkan peran sentral dalam mengkonsolidasikan berbagai pendapat dari warga negara dalam tahap perencanaan kota. Hasil musyawarah masyarakat di tingkat kecamatan berupa Dokumen Rencana Pembangunan Kecamatan dijadikan sebagai acuan penyelarasan penyusunan RKPD Kabupaten serta dikoordinasikan dengan perangkat daerah yang berwenang sebagai masukan penyusunan rencana kerja. Selanjutnya Musrenbang RKPD berjenjang ke Provinsi hingga Nasional. RKPD kabupaten merupakan dasar penyusunan RAPBD (Rancangan Anggaran Pendapan dan Belanja Daerah) yang selanjutnya disahkan menjadi APBD. Norton, (1994:184) desentralisasi administratif bentukan kota/ kabupaten setempat merupakan cara agar warga negara dapat memperoleh akses lokal untuk informasi dan layanan yang merupakan fitur umum di komunitas besar. Secara hukum memberikan ruang pada unit kota/ kabupaten secara terpisah dengan status hukum individu serta kontrol atas anggaran mereka sendiri.

Kemudian terkait dengan penyelenggaraan Musrenbang kecamatan tahun 2018, diketahui merujuk dari Lampiran IV Surat Edaran Bupati Pandeglang Nomor 800/404Bapeda/II/2018 tertanggal 14 Februari 2018 , pagu Indikatif untuk Kecamatan Labuan, Panimbang, Karang Tanjung, Majasari dan Pandeglang sebagai berikut: 
Tabel 2.

Pagu Musrenbang Kecamatan tahun 2019

\begin{tabular}{lll}
\hline No & Kecamatan & Pagu Indikatif \\
\hline 1 & Labuan & $1.289 .400 .000,-$ \\
2 & Panimbang & $1.972 .600 .000,-$ \\
3 & Karangtanjung & $1.822 .300 .000,-$ \\
4 & Majasari & $2.075 .500 .000,-$ \\
5 & Pandeglang & $1.856 .300 .000,-$ \\
\hline
\end{tabular}

Sumber : Data Diolah (BAPEDA)

Badan Perencanaan Pembangunan Daerah Pandeglang, 2018

Tabel di atas merupakan contoh besaran pagu indikatif pembagunan pada tahun 2018 pada beberapa kecamatan yang merepresentasikan zonasi kecamatan yang berada di Kabupaten Pandeglang. Berkaitan dengan itu dari hasil penelitian menunjukan bahwa berdasarkan informasi dari anggota DPRD (Dewan Perwakilan Rakyat Daerah) selama melakukan kegiatan penyerapan aspirasi dan Informasi dari tokoh masyarakat setempat bahwa masyarakat mengeluhkan selama bertahun tahun tidak sedikit terjadi kegiatan pembangunan baik infrastruktur maupun non infrastruktur yang direalisasikan berbanding terbalik dengan usulan masyarakat. Sehingga dampak yang dirasakan adalah menurunya tingkat kepercayaan masyarakat khususnya dengan penyelenggara Musrenbang kecamatan. Kondisi seperti itu terjadi karena kemampuan anggaran, skala prioritas serta fokus pada perwujudan RPJMD Kabupaten Pandeglang. Sebetulnya permasalahanya ada pada bagaimana penyelenggara Musrenbang RKPD kecamatan mampu memberikan pemahaman pada kelompok masyarakat dan pemangku kepentingan lainya agar tidak muncul asumsi atau istilah berbanding terbalik antara usulan dengan realisasi pembangunan. Cross (1970 : 433) sebagaimana dikutip oleh Smith (1985: 202) menjelaskan bahwa kantor wilayah dalam hal ini adalah kecamatan merupakan bagian dari umpan balik yang dibutuhkan oleh pusat pemerintahan dalam melakukan penilaian terhadap dampak kebijakan atas saran. Dalam sistem fungsional camat dan jajaranya mungkin lebih mempunyai pengaruh dalam mengimplementasikan metode metode daripada inisiatif kebijakan utama.

Pemberian pemahaman pada masyarakat dalam penyelenggaraan Musrenbang digambarkan sebagai berikut: 


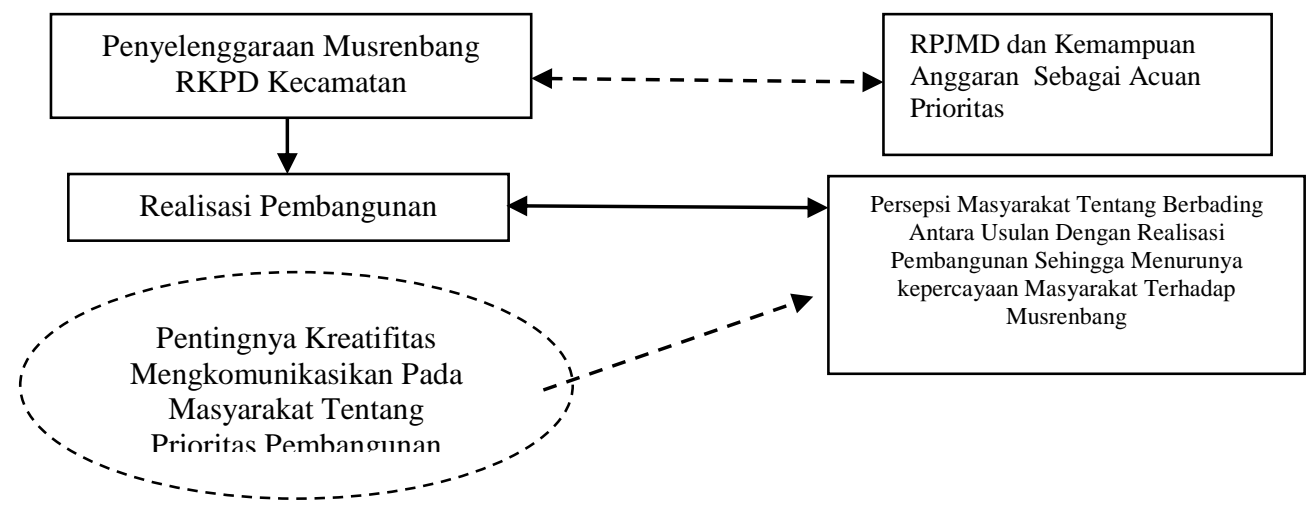

Gambar 4. Pemahaman Penyelenggaraan Musrenbang Pada Masyarakat

Relevansi dan Integrasi Dengan Program Nasional

Diketahui RPJMN (Rencana Pembangunan Jangka Menengah Nasional) dapat diwujudkan salah satunya melalui realisasi Program Strategi Nasional. Realisasi Program Nasional selain menjadi domain remerintah pusat, namun dalan azaz tugas pembantuan pemerintah daerah kabaupaten/kota dan Provinsi beserta perangkat di dalamnya juga berkewajiban untuk ambil bagian dalan realisasi rencana aksi program. Terkait dengan itu diketahui relevansi kecamatan Peraturan Pemerintah Nomor 17 Tahun 2018 Tentang Kecamatan. Secara eksplisit pada pasal 7 menjelaskan bahwa Pembentukan Kecamatan Dalam Rangka Kepentingan Strategis Nasional. Kemudian pada ayat (1) menjelaskan bahwa untuk kepentingan strategis nasional, Pemerintah Pusat dapat menugaskan kepada Pemerintah Daerah kabupaten/kota tertentu melalui gubernur sebagai wakil Pemerintah Pusat untuk membentuk Kecamatan. Wasistiono et all (2006:4) menjelaskan bahwa hakikat tugas pembantuan adalah tugas utuk membantu menjalankan urusan pemerintahan dalam implementasi kebijakan yang bersifat operasional. Oleh karena itu berbagai petunjuk pelaksanaan harus disiapkan oleh yang menugaskan menyangkut standar keberhasilan, waktu penyelesaian, standar biaya, peralatan serta SDM

Dari hasil penelitian diketahui di Kabupaten Pandeglang sendiri, khususnya di kecamatan panimbang masuk dalam zona Program strategi Nasional seperti KEK Tanjung Lesung, bandara banten selatan, jalan tol. Dalam pelaksanaanya Program KEK Tanjung lesung berdasarkan sumber data diolah Bapeda Kabupaten Pandeglang (2018) Prinsip yang dibangun adalah coownership yaitu bahwa kawasan wisata bahari adalah milik bersama untuk itu ada hak-hak masyarakat di dalamnya yang harus diakui namun juga perlindungan yang harus dilakukan bersama. Prinsip co-operation/co management yaitu bahwa kepemilikan bersama mengharuskan, pengelolaan pesisir untuk dilakukan bersama-sama seluruh komponen masyarakat/stakeholder yang terdiri dari pemerintah, masyarakat dan organisasi non pemerintah (ORNOP) yang harus bekerja sama. Partisipasi dalam memberikan dukungan merupakan semangat yang dibangun. Dalam hal ini 
terkait dengan relevansi keberadaan camat/kecamatan Norton, (1994) menjelaskan bahwa dalam bentuk ke empat pada patitisipasi publik di AS bahwa balai kota kecil dan pusat layanan ketetanggaan dibuka dengan harapan membangun korporasi masyarakat yang dipilih dari kelompok aksi sukarela guna memberi saran kepada pejabat pemerintah daerah dan memprakarsai swadaya. Realisasi pada Program KEK ini pemerintah Kabupaten Pandeglang sejauh ini dinilai cukup mampu meberikan dukungan program tersebut hal itu terlihat dari beroperasinya dan tendapat progress pengembangan KEK Tanjung lesung. Tentunya semua itu tidak terlepas dari dukungan pemerintah daerah khusunya Kecamatan yang berada dalam zona untuk memfasilitasi dan memobilisasi stakeholder untuk bersinergi dengan program tersebut.

Kemudian pada pembangunan jalan tol/Jalan bebas hambatan yang mengintegrasikan dengan ibu kota Negara diketahui bahwa progress realisasinya juga dapat dikatakan relatif berjalan. Dalam hal ini camat/ kecamatan memiliki tugas yang cukup berat yaitu melakukan negosiasi dengan masyarakat dalam pembebasan lahan, namun faktanya khusus pembebasan lahan pembangunan jalan tol relatif berjalan. Berbeda dengan pembebasan lahan untuk pembangunan bandara di kecamatan panimbang yang cenderung lamban, hal karena harga yang diminta masyarakat pemilik tahah yang cederung tinggi sehingga berdampak pada keputusan dari presiden untuk menangguhkan proyek pembangunan bandara tersebut. Terkait dengan itu pada dasarnya sebelun presiden menetapkan penanguhan ada upaya yang dilakukan oleh Kabupaten Pandeglang yaitu dengan mengalihkan lokasi pada kecamatan sobang, namun karena lamanya proses administrasi untuk mengalihkan proyek tersebut akhirnya Kabupaten Pandeglang tetap dinilai lamban dalan merealisasikan rencana aksi pembangunan bandara tersebut. Dalam kaitanya dengan camat/kecamatan secara operasional dituntut mampu menjalankan fungsi dan kewenanganya, kreatifitas berkoordinasi dengan mengedepankan prinsip integrasi, sinkronisasi dan kolaborasi pihak terkait. Hal itu dimaksudkan agar bupati sebagai penerima tugas pembantuan dapat terbantu secara optimal dalam merealisasikan target kerja. Merespon hal itu dikutip dari Abbott et all (2015) memperkenalkan konsep orkestrasi sebagai perantara mobilisasi orkestra (yang dilakukan oleh pemerintah) secara sukarela dalam mencapai tujuan pemerintahan bersama. Teori PerantaraOrkestra memberikan model pemerintahan tidak langsung yang model suplemen delegasinya didasarkan pada teori principal-agent.

Selain sebagai Program Strategi Nasional diketahui tata ruang wilayah kecamatan panimbang dan kecamatan Labuan diproyeksikan menjadi Pusat Kegiatan Wilayah Promosi (PKWp). Adapun Rencana Pengembangan Kawasan Kecamatan yang ditetapkan oleh Pemerintah Kabupaten Pandeglang sebagai berikut: 
Tabel 3.

Rencana Pengembangan Kawasan Kecamatan

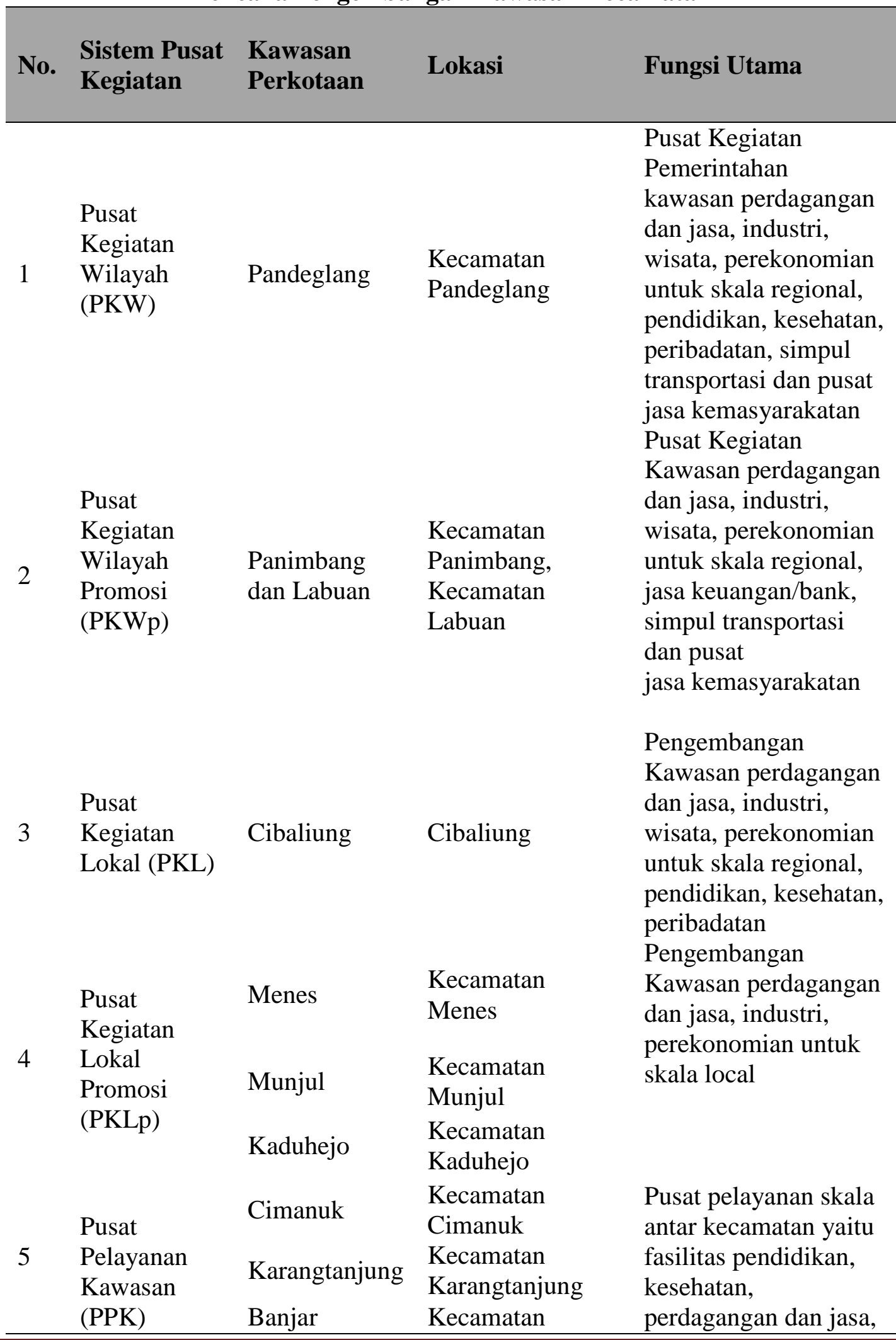




\begin{tabular}{clll}
\hline $\begin{array}{l}\text { Sistem Pusat } \\
\text { Kegiatan }\end{array}$ & $\begin{array}{l}\text { Kawasan } \\
\text { Perkotaan }\end{array}$ & Lokasi & Fungsi Utama \\
\cline { 2 - 3 } & Majasari & $\begin{array}{l}\text { Banjar } \\
\text { Kecamatan } \\
\text { Majasari }\end{array}$ & \\
& Kecamatan \\
& Cadasari & $\begin{array}{l}\text { Cadasari } \\
\text { Kecamatan } \\
\text { Sumur }\end{array}$ & $\begin{array}{l}\text { Sumur } \\
\text { Kecamatan } \\
\text { Cikeusik } \\
\text { Kecamatan Saketi }\end{array}$ \\
& Saketi & Kecamatan \\
& Pagelaran & \\
\hline
\end{tabular}

\section{Sumber: Data Diolah (BAPEDA) Badan Perancanaan Pembangunan Daerah Pandeglang, 2017}

Berdasakan tabel dan uraian di atas. Artinya dengan keberadaan Program Strategi Nasional serta Rencana Pengembangan Kawasan Kecamatan yang telah ditetapkan, Pemerintah Kabupaten Pandeglan dan Kecamatan diharapakan tidak hanya mampu merealisasikan rencana aksi tugas pembantuan Program Strategi Nasional. Namun juga harus mampu mengambil kesempatan atau implikasi positif dengan penciptaan nilai tambah baik yang berdaya dampak pada penerimaan daerah maupun daya dampak rente perekonomian bagi masyarakat dari keberadaan Program Strategi Nasional. Sehingga dengan itu akan menjadikan Kabupaten Pandeglang sebagai daerah yang memiliki peningkatan optimal pada kinerja pembangunan daerah.

Dari hasil penelitian diketahui bahwa kesempatan itu belum dimanfaatkan secara optimal. Hal itu terlihat dari selain rendahnya IPM Kabupaten Pandeglang secara nasional sehingga masuk dalam daftar merah IPM Nasional. Berdasarkan hasil wawancara yang dilakukan dengan pengamat pembangunan kabupten sekaligus sebagai tokoh masyarakat Kabupaten Pandeglang memiliki kecenderungan hanya menunggu dan merealisasikan program strategi nasional saja namun tidak memanfaatkan kesempatan dari momentum itu untuk inovatif dalam merencanakan pembangunan daerah khususnya dalam pertumbuhan perekonomian. Terkait dengan iu dan dalam kondisi yang seperti itu pada dasarnya inisiatif bisa dimulai dari camat/ kecamatan dalam rangka merepresentasikan prinsip fleksibilitas lokalisasi. Burn et al, (1994:95) menjelaskan bahwa pengembangan pendekatan yang lebih terintegrasi dan fleksibel merupakan komponen penting dari desentralisasi di sekitar sebagai cara mengkompensasi terhadap hilangnya beberapa skala ekonomi yang dibutuhkan lokalisasi.

\section{PENUTUP}

Dalam konteks pembangunan secara makro perlu disadari bahwa pembangunan pemerintah daerah otonom merupakan bagian yang terintegrasi 
dengan perwujudan pembangunan secara nasional. Faktor - faktor lokalitas dalam pemerintahan daerah seperti halnya kultur serta konsesus nilai yang sudah menjadi primordialisme masyarakat lokal merupakan isu yang sejatinya harus dielaborasi dalam kebijakan pembangunan sehingga pembangunan dapat berjalan, seiring sejalan dengan terciptanya harmoni itu sendiri. Birokrasi sebagai salah satu instrument mengemban tugas besar berupa harmonisasi hubungan antara masyarakat dengan pemerintah dan pemerintah daerah. Camat/kecamatan sebagai bagian dari birokrasi perangkat daerah otomom dalam kewenangan kewilayahan menjadi salah satu penentu penciptaan harmonisasi tersebut melalui tugas, fungsi, kewenangan serta kreatifitas dan inovasi dalam menjalankan kapasitas yang dimiliki. Posisinya camat/ kecamatan sebagai medium untuk tidak terjebak pada kepentingan subyektif merupakan prinsip yang harus digaris bawahi.

Perwujudan pembangunan yang teritegrasi pada lokus badan hukum sosial politik bentukan Negara yaitu desa sebagai bagian yuridiksi pemerintah daerah dan wilayah kerja camat/kecamatan, merupakan sebuah tanggung jawab besar camat/ kecamatan sebagai simpul Pembina dan pengawas yang menghubungkan antara pemerintah daerah dengan desa. Desa sebagai badan hukum sosial politik bentukan Negara memiliki otonomi pengelolaan dalam pembangunan serta partisipasi masyarakat. Artinya dengan itu kecamatan memiliki batasan untuk melakukan intervensi secara hirarki struktural namun kecamatan secara moral kelembagaan memiliki tanggung jawab atas tercapainya realisasi pembangunan desa melalui kapasitas membina dan mengawasi. Dengan itu diperlukan kemauan dari camat/kecamatan untuk berkreasi dalam menjalankan tugas, fungsi dan kewenanganya sehingga terjalin kordinasi, sinergi, kolaborasi yang baik, baik dengan desa, pemerintah daerah maupun pihak lain yang terkait. Terciptanya kondisi yang seperti itu secara tidak langsung akan berimplikasi pada efiktifitas realisasi proses pembangunan yang dilaksanakan oleh desa dan efektifitas kecamatan serta pemerintah daerah dalam mengeban tugas dan fungsi pembinaan serta pengawasan.

Tugas dan fungsi kecamatan dalam memfasilitasi partisipasi masyarakat pada perencanaan pembangunan tidak sedikit terbentur dengan persepsi masyarakat bahwa seremonial yang dilaksanakan adalah seremonial semu, dimana pada pelaksanaan pembangunan nantinya terjadi pola berbanding terbalik antara usulan masyarakat dengan pembangunan yang direalisasikan. Pada dasarnya persepsi tersebut akan dapat dieliminir jika camat/kecamatan mampu membangun kepercayaan pada masyarakat dengan memberikan pemahaman yang mendasar tentang esensi dan mekanisme dari penyelenggaraan perencanaan pembangunan tersebut dengan menitik beratkan pada kemampuan sumber daya anggaran pemerintah daerah serta skala prioritas yang menjadi agenda pembangunan daerah.

Tugas pembantuan pemerintah daerah pada program strategi nasional atau dengan kata lain tuntukan orkestrasi pemerintah daerah pada pembangunan nasional pada dasarnya hal itu merupakan sebagai sebuah kesempatan yang dimiliki oleh daerah. Kesempatan dimaksudkan tidak hanya pada merealisasikan rencana aksi, namun lebih pada mengambil peluang atas keberadaan program tersebut. Seperti halnya merumuskan kebijakan yang mengarah pada terciptanya implikasi yang menguatkan tercapainya agenda 
pembangunan daerah yang telah ditetapkan.

Berdasarkan uraian tersebut di Kabupaten Pandeglang sendiri ketika melihat tingkat keberhasilan kinerja camat/ kecamatan dalam pembangunan secara adminisratif dapat dikatakan cukup berhasil. Hal itu ditandai dengan adanya kemauan dari camat untuk berkreasi dan berinovasi dalam menjalankan tugas, fungsi dan kewenanganya terhadap realisasi agenda pembangunan baik daerah maupun tutututan orkestrasi program pemerintah pusat ditengah tantangan yang dihadapi khususnya kultur serta nilai nilai yang menjadi primordialisme di kalangan masyarakat maupun di desa secara kelembagaan.

Adapun beberapa hal yang menjadi catatan seperti pembebasan lahan pembangunan bandara yang dinilai lamban, kemudian belum mampunya memberikan pemahaman pada masyarakat tentang mekanisme perencanaan pembangunan dalam seremonial Musrenbang sehingga menghasilkan persepsi yang berbeda di masyarakat. Serta belum termanfaatkanya keberadaan program strategi nasional sebagai momentum penguatan pencapaian agenda pembangunan Kabupaten Pandeglang baik itu inisiasi yang dimulai dari camat/ kecamatan maupun kebijakan yang diambil oleh Bupati. Pada dasarnya catatan tersebut merupakan sebuah kekurangan sehingga yang menjadi saran adalah halhal yang sebaliknya. Kemudian ketika kinerja camat/kecamatan dalam pembangunan dilihat dari implikasi terhadap pertumbuhan IPM, maka dapat dikatakan belum cukup berhasil hal itu ditandai dengan belum signifikanya pertumbuhan IPM antara tahun 2015 hingga 2018 hanya mengalami peningkatan sebesar 0,68. Belum signifikanya pertumbuhan IPM disinyalir salah satunya disebabkan karena belum optimalnya camat/ kecamatan dalam menjalankan tugas, fungsi dan kewenagan terhadap kekurangan - kekurangan yang ada.

\section{DAFTAR PUSTAKA}

Abbott, Kenneth W.et al, 2015. Two Logics of Indirect Governance: Delegation and Orchestration. British Journal of Political Science / FirstView Article / July 2015, pp 1 - 11 DOI: 10.1017/ S0007123414000593, Published online: 21 July 2015

Alrasyid, Harun,M, Reformasi Birokrasi. Jurnal Madani Edisi I/Mei 2007

Bantenheadline,29 Maret 2018. Tingkat Kemiskinan, IPM \& Lama Sekolah di Pandeglang Tak Berubah Signifikan. diperoleh 11 Juni 2018, dari, http://bantenheadline.com

Burns, Danny, et.al., 1994. The Politic of Decentralization, Revitalising Local Democracy. Hongkong : MacMillan.

Butsankom, et .al.,. 2016. The Development Effectiveness Management Modelfor sub-district secondary school. Academic Journals. Vol 11 (19)

Boonstri,Karn \& Phiritasamith, Sucheep, 2016. Development of Participative Management of Subdistrict Administrative Organizations in Songkhla Province. International Journal of the Computer, the Internet and Management. Vol.24 No.2 (May - August, 2016) pp. 64-68.

Hamudy, Ilham, A, 2009. Peran Camat di Era Otonomi Daerah. Bisnis \& Birokrasi, Jurnal Ilmu Administrasi dan Organisasi, 
Jan-Apr 2009, hlm. 53-58 Volume 16, Nomor 1 ISSN 0854-3844.

Kabar24, 22 Maret 2017. UNDP: Indeks Pembangunan Manusia Indonesia Naik Pesat. diperoleh 22 Juni 2017, dari http://kabar24. bisnis.com.

Kemmochi, Mai, et al. 2016. Research Concerning The State Of Decentralization Within Cities and The Participation In City Planning . Journal of the City Planning Institute of Japan, Vol.51 No.3, October, 201

Kurasawa, Aiko.2015.Kuasa jepang di Jawa (Perubahan Sosial di Perdesaan 1942-1945). Diterjemahkan oleh Hermawan Sulistyo. Depok: Komunitas Bambu.

Miles,M.B, Huberman, A.M, dan Saldana,J. 2014. Qualitative Data Analysis, A Methods Sourcebook Edition 3. USA : Sage Publications.

Mugito, 2012. Usaha - Usaha Penguatan Peran dan Fungsi Kecamatan di Era Otonomi Daerah. Jurnal Ilmiah Administrasi Publik Vol. XIII, No. 1, Juni 2012

Norton, Allan, 1994. International Handbook of Local and Regional Government, A Comparative Analysis of Advenced Democracies, Adwarad Elgar, UK.

Peraturan Bupati Pandeglang No. 24 tahun 2013, tentang Pelimpahan Sebagian Kewenangan Bupati Kepada Camat.

Peraturan Bupati Pandeglang No. 24 Tahun 2015 Tentang Pedoman Umum Pengelolaan Dana Desa
Peraturan Bupati Pandeglang No. 66 Tahun 2016 tentang Tata kerja Perangkat daerah Kecamatan

Peraturan Bupati Pandeglang No. 3 Tahun 2017 Tentang Kewenangan Desa

Peraturan Bupati Pandeglang No. 6 Tahun 2017 Tentang Pedoman Umum Pengelolaan Dana Desa.

Peraturan Pemerintah Nomor 12 Tahun 2017 Tentang Pembinaan dan Pengawasan Penyelenggaraan Pemerintahan Daeah

Poskota, Rabu, 23 Maret 2016. Rano Karno Soroti Kemiskinan dan Pendidikan di Pandeglang. diperoleh 11 April 2017, dari, http://poskotanews.com

Smith, Brian C, 1985. Decentralization: The Territorial Dimension of the State.London : George Allen \& Unwin.

Surat Edaran Bupati Pandeglang Nomor 601/1474-DPMPD/2017 Tentang Program Prioritas Pembangunan Desa Tahun 2017

Turner, Mark and Hulme David, 1997, Governance, Administration and Development: Making the State Work. Macmillan.

Undang - Undang Nomor 23 Tahun 2014, tentang Pemerintahan Daerah.

Wasistiono, Sadu et al, 2009. Perkembangan Organisasi Kecamatan Dari Masa ke Masa. Bandung : Fokus Media.

World Bank, 2008. United Cities and Local Governments. Washington D.C. 